\title{
Comparative therapeutic effects of mesenchymal stem cells versus their conditioned media in alleviation of CCL4-induced liver fibrosis in rats : Histological and biochemical study
}

Original Article

\author{
Sara M. Abdel Aal', Shaimaa A. Abdelrahman' ${ }^{1}$ and Nermin Raafat ${ }^{2}$ \\ ${ }^{I}$ Department of Histology and Cell Biology, ${ }^{2}$ Department of Medical Biochemistry, Faculty of \\ Medicine, Zagazig University, Zagazig
}

\begin{abstract}
Background: Viral hepatitis, drug abuse and metabolic diseases cause liver injury. Stem cell conditioned media (CM) alone can offer organ repair as compared to stem cell therapy.

Objective: This study was designed to investigate role of bone marrow derived mesenchymal stem cells (BM-MSCs) CM in comparison to BM-MSCs in amelioration of liver injury in carbon tetrachloride $(\mathrm{CCl} 4)$ induced liver fibrosis

Materials and Methods: PKH26 -labeled MSCs were transplanted into one albino rats group with CC14 induced liver fibrosis. MSCs-CM was injected in another group. Hematoxylin and eosin staining, Masson trichrome for collagen, Periodic Acid Schiff for glycogen, immunohistochemical and biochemical analysis were done to compare the morphological and functional liver regeneration among groups. The expression differences of CYP7A1, CYP27A1, glutathione reductase, glutathione peroxidase, albumin and interleukins were examined by real-time polymerase chain reaction (RT-PCR) and enzyme linked immunosorbent assay (ELISA).

Results: MSCs and CM transplantation significantly increased antioxidant enzymes activity in injured liver. Also, gene expression levels attenuated by $\mathrm{CCl}$, were increased up to basal levels. $\mathrm{CCl} 4$ group showed different degrees of pathology with some severely affected lobules. MSCs group showed nearly normal organization apart from some dilated sinusoids and vacuolated cells. MSCs-CM injection revealed almost normalized liver histological and immunohistochemical picture.

Conclusion: BM-MSCs conditioned medium is found to play a predominant therapeutic role in chronic liver fibrosis as compared to BM-MSCs.
\end{abstract}

Key Words: CCL4, conditioned media, liver fibrosis, mesenchymal stem cells, rats.

Revised: 07 March 2019, Accepted: 11 July 2019

Corresponding Author: Shaimaa A. Abdelrahman, Assistant professor, Department of Histology and Cell Biology, Faculty of Medicine, Zagazig University, Zagazig, Egypt, Tel.: 002 01000646631, E-mail: shimaaali576@gmail.com.

ISSN:2536-9172, June 2019, Vol. 3, No. 1

\section{INTRODUCTION}

Liver cirrhosis due to hepatitis B virus (HBV) or hepatitis $\mathrm{C}$ virus (HCV) infection is very common worldwide, especially in Egypt $^{[1]}$. Schistosomiasis is another cause of hepatic fibrosis and portal hypertension, contributing to the death of over half a million people a year ${ }^{[2]}$. Liver fibrosis is characterized by hepatic stellate cell (HSC) proliferation and differentiation to myofibroblast-like cells, which deposit extracellular matrix (ECM) and collagen. Poynard et al. ${ }^{[3]}$ stated that HSC-mediated pericental fibrosis plays an important role in the development of hepatic cirrhosis. Therefore, prevention of HSC activation has been the most promising therapeutic strategy for this disease $^{[3]}$.

Liver transplantation has been considered the most effective therapy for patients with advanced liver diseases. Unfortunately, availability of donor livers is limited, over $10 \%$ of patients die while waiting for liver transplantation. Among patients who received liver transplants, the survival rate has been $94 \%$ at 3 months, $88 \%$ at 1 year and $79 \%$ at 3 years ${ }^{[4]}$. In developing countries, the picture is alarming, and yearly mortality rates have reached $49 \%{ }^{[5]}$.

Mesenchymal stem cells (MSCs) are multipotent adult stem cells which have emerged as an attractive candidate for liver repair. They have been shown to form functional hepatocytes in vitro $^{[6]}$ and have the ability to secrete soluble factors stimulating endogenous parenchymal cells to support tissue recovery ${ }^{[7]}$. Besides treating acutely damaged tissue, MSCs also have the potential to reduce chronic fibrogenesis through the modulation of inflammation, collagen deposition, and remodeling. The role of MSCs in liver regeneration remains controversial. Although several studies have suggested that MSC transplantation can reduce liver fibrosis in animal models of cirrhosis $^{[1,8,9,10 \text {, and } 11]}$, other studies failed to demonstrate a beneficial role of MSCs in the repair process of fibrogenesis ${ }^{[12,13]}$.

Carbon tetrachloride $(\mathrm{CCl} 4)$ induced liver fibrosis 
represents a classical experimental model frequently used to study hepatic fibrosis and most closely resemble that of human liver cirrhosis ${ }^{[10,14,15]}$. CCl4 is bio-activated by cytochrome-P4502EI to generate free radicals that trigger a cascade of events resulting in hepatic fibrosis ${ }^{[16]}$.

MSCs are known to be selectively recruited to injured tissue using comparable mechanisms of recruitment, i.e. trans-endothelial migration directed by chemokine gradient ${ }^{[17]}$. Various studies on stem cell-derived secreted factors revealed that the secreted factors alone without the stem cell itself may cause tissue repair in various conditions that involved organ damage. The secreted factors are referred to as secretome, microvesicles, or exosome that can be found in the medium where the stem cells are cultured, thus, the medium is called conditioned medium $(\mathrm{CM})^{[18]}$.

In the present study, we studied the therapeutic effects of MSCs in comparison to their culture medium alone (MSC-CM, containing various MSC secreted soluble factors) on chronic liver fibrosis in rats.

\section{MATERIALS AND METHODS}

\section{Site of the study}

This study was performed in the Department of Histology and Cell Biology and Medical Biochemistry department, Faculty of Medicine and Medical and Scientific Research Center, Zagazig University, Egypt.

\section{Animals}

Thirty-two adult healthy male albino rats (14-18 weeks) weighing 180 - 200 grams were used in this study. Rats were obtained from the breeding animal house of the Scientific and Medical Research Center, Faculty of Medicine, Zagazig University, Egypt. They were housed in a temperature-controlled and light-controlled room (12 h light/dark cycles) with free access to food and water. All experimental procedures were performed according to guidelines of the Institutional Animal Care and Use Committee of the Faculty.

\section{Induction of chronic liver fibrosis}

To induce liver fibrosis, rats received 12 consecutive subcutaneous injections $(0.5 \mathrm{~mL} / \mathrm{kg}$ body weight $)$ of $\mathrm{CCl} 4$ dissolved in olive oil twice per week for 6 weeks. Injection of olive oil alone served as a control (11).

\section{Experimental protocol}

The rats were divided into four groups, 8 animals in each:
Group I (control): received $200 \mu$ l of olive oil at time of injection.

Group II (CCl4): injected subcutaneously with $\mathrm{CCl} 4$ as mentioned.

Group III (MSCs): injected with $\mathrm{CCl} 4$ as in group II then $1 \times 10^{6}$ MSCs were infused into the tail vein six weeks later.

Group IV (MSC-CM): injected with $\mathrm{CCl} 4$ as in group II then received $200 \mu \mathrm{l}$ MSC culture medium MSCs-CM into tail vein twice per week for 3 consecutive weeks six weeks after $\mathrm{CCl} 4$ injections.

\section{Sampling}

Three weeks after treatment, rats of all groups were sacrificed with intraperitoneal injection of $25 \mathrm{mg} / \mathrm{kg}$ sodium thiopental ${ }^{[19]}$. Venous blood and liver tissue samples were taken for biochemical and histological study, respectively.

\section{Isolation and culture of BM-derived MSCs}

According to Raafat et al. (2015), Bone marrow was harvested by flushing the tibiae and femurs of 6-weeks-old male albino rats with Dulbecco's modified Eagle's medium (DMEM) supplemented with 10\% fetal bovine serum. Nucleated cells were isolated with a density gradient. Cells were incubated at $37^{\circ} \mathrm{C}$ in $5 \%$ humidified $\mathrm{CO} 2$ for 12 14 days, until formation of large colonies (80 90\% confluence). The culture was washed with phosphate buffered saline (PBS) and released with $0.25 \%$ trypsin in $1 \mathrm{~mL}$ EDTA $\left(5 \mathrm{~min}\right.$ at $\left.37^{\circ} \mathrm{C}\right)$. After centrifugation, the cells were re-suspended with serum-supplemented medium. Mononuclear cells were cultured in high-glucose DMEM (GIBCO/BRL) with 2mmol/L L-glutamine, 10\% FBS and $1 \%$ penicillin streptomycin-amphotericin $\mathrm{B}$ mixture (GIBCO/BRL). Non-adherent cells were poured off. When the cells reached $70-80 \%$ confluence at day 10 after incubation, cells were harvested with $0.25 \%$ trypsinEDTA (GIBCO/BRL) and reseeded $1 \times 10^{5}$ cells/well (11)

\section{Characterization of BM-derived MSCs}

MSCs at day 14 were characterized by their adhesiveness and fusiform, star or spindle shape. By flow cytometric evaluation, MSCs express CD105, CD73 and CD29 on their cell surface and do not express CD34, CD45 or MHC-II.

\section{Preparation of $M S C-C M$}

For the generation of MSC-CM, cells were allowed to grow to $80-90 \%$ confluence (approximately $3 \times 10^{6}$ MSCs per 55- $\mathrm{cm}^{2}$ dish), washed thoroughly, and cultured in $10 \mathrm{~mL}$ serum-free $\alpha$-MEM. Conditioned medium was 
collected 24 hours later. Conditioned growth medium was concentrated 25-fold through ultrafiltration units (Millipore, Bedford, MA).

Labeling of stem cells with Paul Karl Horan 26 (PKH-26) (red fluorescence cell linker)

MSCs were harvested during the 3rd passage and were labeled with PKH26 dye ${ }^{[20]}$. Cells were centrifuged and washed twice in serum free medium. Cells were pelleted and suspended in dye solution.

Detection of homing of stem cells: liver tissue was examined with a fluorescent microscope (Olympus BX50F4, No. 7M03285, Tokyo, Japan) to detect and trace the cells stained with PKH26.

\section{Biochemical analysis \\ Liver function assessment}

Serum alanine transaminase (ALT), aspartate transaminase (AST) and alkaline phosphatase (ALP) activities and serum albumin level were determined using kits provided by Elitech (France). They were determined spectrophometrically ${ }^{[21]}$.

\section{Hepatic oxidant-antioxidant markers assessment}

Malondialdehyde level (MDA) ${ }^{[22]}$, Reduced glutathione $(\mathrm{GSH})^{[23]}$ and superoxide dismutase enzyme activity $(\mathrm{SOD})^{[24]}$ were performed according to the respective manufacturer's instructions (Biodiagnostic Tahreer St., Dokki, Giza, Egypt).

\section{Enzyme linked immunosorbent assay (ELISA)}

Serum in all rat groups was collected at days 5, 10 and 15 post-transplantation and assayed for IL10 production with an IL10 enzyme linked immunosorbent assay (ELISA) Quantitation kit (Invitrogen, United States) according to the manufacturer's recommendation.

\section{Quantitative real time PCR analysis}

RNA was extracted from the liver tissue in each experimental rat using RNeasy Mini kit (Qiagen). RT (reverse transcription) was done with RT kit (Promega). Real-time PCR of target gene copy numbers in relation to glyceraldehyde-3-phosphate dehydrogenase (GAPDH) transcripts was carried out using individual primers mentioned in table 1. Gene expression levels were quantified using a SYBR Green kit (Qiagen, Hilden, Germany). Data were analyzed using MxPro QPCR Software (Agilent technologies).

\section{Histological and immunohistochemical study}

(a) The liver from each animal was carefully dissected and the specimens were immediately immersed in $10 \%$ formol saline for $48 \mathrm{~h}$ to be processed to prepare $5 \mu \mathrm{m}$-thick paraffin sections and stained with hematoxylin and eosin (H\&E) to display the histological details, with Masson trichrome (MT) to demonstrate the collagen fibers and with periodic acid schiff (PAS) to demonstrate glycogen content according to Bancroft and Gamble ${ }^{[25]}$.

(b) The immunohistochemical staining of alpha smooth muscle actin ( $\alpha$-SMA) was performed according to Ramos-Vara et al. ${ }^{[26]}$. Liver tissue sections were stained using antigen retrieval technique. The primary antibody used was immunoglobulin $\mathrm{G}$ ( $\mathrm{IgG}$ ) type for detection of $\alpha$-SMA (Sigma Biochemical, St. Louis, Missouri, USA). For negative control, the primary antibody was replaced by PBS. This immunohistochemical technique was carried out at the Department of Pathology, Faculty of Medicine, Cairo University.

\section{Quantitative morphometrical measurements}

Sections stained with PAS, Masson trichrome and immunohistochemical reaction were morphometrically measured using Leica Qwin 500 Image Analyzer Computer System (England) at Pathology Department, Faculty of Dentistry, Cairo University. Area\% of collagen fibers in MT-stained sections and optical density of hepatocytes glycogen and $\alpha$-SMA immunoreaction were measured at magnification of 400X. All parameters were measured for randomly chosen five fields per section in total five sections from 8 rats in each group.

\section{Statistical analysis}

The results for quantitative variables were expressed as mean \pm standard deviation. Statistical significance was determined by one-way analysis of variance for differences between the means of different groups Differences between groups were considered significant when $P$ values were $<0.05$. All statistical analyses were performed with the use of SPSS, version 10 (SPSS Inc).

\section{RESULTS}

\section{Biochemical Results}

\section{Characterization of cultured MSCs by flow cytometry}

Flow cytometric analysis of cell surface markers on gated cells showed positive surface expression of CD29 and CD105 (PE labelled) ${ }^{[27]}$ while the majority of cells showed negative expression of CD34 and CD45 (FITC labelled $)^{[28]}$. This surface marker expression patterns corresponded to BM-MSC according to the International Society of Cellular Therapy System (Fig. 1).

\section{Liver function tests}

In the present study, rats given $\mathrm{CCl} 4$ showed a highly significant increased activities of serum ALT, AST, and ALP $(P<0.001)$ and albumin level as compared to the control group (Table 2). In addition, there was a significant decrease in serum levels of albumin $(P<0.05)$. 
Normalization of serum level of ALT, AST, ALP activities and serum albumin level were observed in the MSCs and MSCs-CM groups when compared with the CCl4 group. The levels of those parameters in these groups and the control group were non-significantly different (Table 2 ).

\section{Effect of MSCs and CM on markers of oxidative stress in hepatic tissue}

MDA was a highly significantly $(P<0.001)$ increased in hepatic tissue of $\mathrm{CCl} 4$ injected rats as compared to other rats. There was a highly significant $(P<0.001)$ decrease in the levels of GSH and SOD in liver tissue as compared to normal control group.

MSCs or CM treatment of $\mathrm{CCl} 4$ injected rats showed a highly significant decrease $(P<0.001)$ in MDA levels and a significant increase in GSH and SOD ( $P<0.05$ and $P<0.01$ respectively) as compared to CCl4 induced liver fibrosis rats (Table 3 )

\section{IL10 level by ELISA}

ELISA assay indicated that serum IL10 production after injection of MSCs and their culture medium was higher than $\mathrm{CCl} 4$ group (Fig.2a).

\section{Comparison of gene expression analysis among studied groups}

RT-PCR analysis demonstrated that the expression levels of the CYP7A1, CYP27A1, Gsr, Gpx1 and albumin genes expression in response to $\mathrm{CCl} 4$ treatment were lower than those of MSCs and CM treated groups (Figs. 2b and c). To further explore the effectiveness of intravenouslyinjected MSC treatment MMP9 gene was found to be highly expressed in MSCs and MSCs-CM groups whereas TIMP1 expression was the lowest in MSCs-CM group (Fig. 2c). Furthermore, cytokine expression was also assayed to detect whether the immune response played a crucial role in the differential treatment response among the two experimental groups. PDGF, an important fibrosis enhancer, was significantly highest in $\mathrm{CCl} 4$ group. TNF $\alpha$ and TGF $\beta$ were significantly lower in MSCs and MSCs$\mathrm{CM}$ groups than in $\mathrm{CCl} 4$ group and $\mathrm{CM}$ group had the lowest expression. Interestingly, IL10 gene expression was highly expressed in MSCs and CM groups (Fig. 2d)

\section{Histological and immunohistochemical results}

\section{Characterization of MSCs in liver tissue by fluorescent microscopy}

Fluorescent microscope examination of liver sections of stem cells-treated group III showed PKH26-labeled stem cells appearing as bright dots which indicate homing of MSCs in the liver tissue (Fig. 2e).

\section{Haematoxylin \& Eosin staining}

$\mathrm{H}$ and $\mathrm{E}$ stained liver sections of control group showed normal polygonal classic hepatic lobules with hepatocytes radiating from the cenal vein, portal areas were seen at the periphery of the lobules. Hepatocytes had vesicular nuclei and acidophilic cytoplasm, some hepatocytes were binucleated. Blood sinusoids could be seen in-between hepatocytic cords. Sinusoids and central vein are lined with flat endothelial cells (Fig. 3a and b). $\mathrm{CCl} 4$ treated group showed severely affected lobules with different changes in the form of detached endothelial lining of central vein, cellular and fatty infiltration in-between hepatocytes and congested blood sinusoids were also evident (Fig. 3c). Other sections of the same group showed that most hepatocytes have vacuolated cytoplasm and dark nuclei but some cells still have deep acidophilic cytoplasm, the portal vein was congested and dilated with detached endothelial lining, hepatic artery and bile duct could be seen (Fig. 3d). MSCs treated group showed nearly normal organization of hepatic lobules with dilated sinusoids, some cells were vacuolated whereas others have deep acidophilic cytoplasm and some cells were binucleated (Fig. 3e). The portal area showed dilated portal vein, fatty infiltration and cellular infiltration were evident (Fig. 3f). MSC-CM treated group showed normal organization of hepatic lobules, hepatocytes were radiating from the central vein which was lined with intact endothelium, portal areas were seen at the periphery of the lobules, blood sinusoids were seen between normal shaped hepatocytic cords and some binucleated cells could be seen (Fig. 3g). : The higher magnification of some sections showed normal shaped portal vein (PV), hepatic artery and bile duct with mild cellular infiltration. Most hepatocytes had acidophilic cytoplasm and vesicular nuclei with some dilated sinusoids could be seen (Fig. 3h)

\section{Periodic acid Schiff (PAS) staining}

PAS stained sections of control group showed strong positive reaction of glycogen granules in the cytoplasm of hepatocytes (Fig. 4a). On the other hand, weak positive reaction was observed in $\mathrm{CCl} 4$ treated group (Fig. 4b). Positive PAS reaction was observed in some hepatocytes of MSC-treated group (Fig. 4c) and strong positive PAS reaction of glycogen granules in the cytoplasm of hepatocytes of MSC-CM treated group were found (Fig. 4d).

\section{Masson Trichrome (MT) staining}

MT stained sections of control group showed few collagen fibers around central vein and portal area (Figs. 5a and b), CCl4 treated group showed marked increase in collagen deposition around central vein and portal area (Figs. 5c and d) in addition to presence of bridging fibrosis areas in some sections (Fig. 5e). Moderate amount of collagen was noticed in stem cells treated group (Figs. 5f and g) and few collagen fibers were detected around central vein and in portal area in MSC-CM treated group (Figs. 5h and i).

\section{Immunohistochemistry}

Immunohistochemistry of $\alpha$-smooth muscle actin $(\alpha$-SMA) showed weak positive immunoreaction in the wall of the central vein and in-between hepatocytes in control group (Fig. 6a). Strong positive $\alpha$-SMA 
immunoreaction in the wall of the central vein and in-between the hepatocytes was found in $\mathrm{CCl} 4$ treated group (Fig. 6b). Moderate expression of $\alpha$-SMA immunoreaction was detected in the wall of the central vein and in-between the hepatocytes in MSC treated group (Fig. 6c). MSC-CM treated group showed weak immunoreaction of $\alpha$-SMA (Fig. $6 d$ ).

\section{Morphometrical and statistical results}

Statistical analysis of the morphometrical results of optical density of $\alpha$-SMA and area $\%$ of collagen fibers among the different studied groups using ANOVA test showed a highly statistical significant difference as the $P$ value $<0.001$. Its highest mean was of the fibrosed $\mathrm{CCl} 4$ group then MSCs group or MSC-CM group and the lowest level that of the control rats. No significant difference between the control rats and the treated MSCs or MSC-CM was detected as regards the area \% of both $\alpha$-SMA and collagen fibers while there was highly statistical significant difference between the treated MSCs or MSC-CM and CCl4 group (Table 4).

Statistical analysis of the morphometrical results of optical density of liver glycogen showed a highly statistical significant difference as the $P$ value $<0.001$. the lowest mean was that of $\mathrm{CCl} 4$ group and the highest was of control group. No significant difference between the control rats and the treated MSCs or MSC-CM while highly statistical significant difference observed between the treated MSCs or MSC-CM and CCl4 group (Table 4).

Table 1: Primers sequence of GAPDH, microsomal cholesterol $\alpha$-hydroxylase (CYP7A1), mitochondrial sterol 27-hydroxylase (CYP27A1), glutathione reductase (Gsr), glutathione peroxidase (Gpx1), albumin, interleukin 10 (IL10), tumor necrosis factor alpha (TNF $\alpha$ ), transforming growth factor beta (TGF $\beta$ ), matrix metalloproteinase 9 (MMP9), tissue inhibitor of metalloproteinase (TIMP) and platelet derived growth factor (PDGF).

\begin{tabular}{|c|c|}
\hline Target & Sequence \\
\hline GAPDH & $\begin{array}{l}\text { F, 5'- ACCACAGTCCATGCCATCAC-3' } \\
\text { R, 5'- TCCACCACCCTGTTGCTGTA-3' }\end{array}$ \\
\hline Сур7А1 & $\begin{array}{l}\text { F, 5'- CACCATTCCTGCAA-CCTTTT -3' } \\
\text { R, 5'- GTACCGGCAGGTCATTCAGT -3' }\end{array}$ \\
\hline Сур27A1 & $\begin{array}{l}\text { F, 5'- ATGTGGCCAATC TTCTCTACC -3' } \\
\text { R, 5'- GGGAAGGAAAGTGACATAGAC -3' }\end{array}$ \\
\hline Gsr & $\begin{array}{l}\text { F, 5'-GAAGTCAACGGGAAGAAGTTCACTG-3' } \\
\text { R, 5'- CAATGTAACCGGCACCCACAATAAC -3' }\end{array}$ \\
\hline Gpx1 & $\begin{array}{l}\text { F,5'-AGTTCGGACATCAGGAGAATGGCA-3' } \\
\text { R, 5'- TCACCATTCACCTCGCACTTCTCA -3' }\end{array}$ \\
\hline Albumin & $\begin{array}{l}\text { F, 5'- GCAAACTGCAGGCTTGCTGTGATA-3' } \\
\text { R, 5'- AAGTCAGCAGCTATTGAGGGCAGA-3' }\end{array}$ \\
\hline IL-10 & $\begin{array}{l}\text { F, 5'- CAGACCCACATGCTCCGAGA-3' } \\
\text { R, 5'- CAAGGCTTGGCAACCCAAGTA-3' }\end{array}$ \\
\hline TNF- $\alpha$ & $\begin{array}{l}\text { F, 5'- AACTCGAGTGACAAGCCCGTAG-3' } \\
\text { R, 5'- GTACCACCAGTTGGTTGTCTTTGA-3' }\end{array}$ \\
\hline TGF- $\beta$ & $\begin{array}{c}\text { F, 5'- TGCGCCTGCAGAGATTCAAG-3' } \\
\text { R, 5'- AGGTAACGCCAGGAATTGTTGCTA-3' }\end{array}$ \\
\hline MMP-9 & $\begin{array}{l}\text { F, 5'- AAATGTGGGTGTACACAGGC-3' } \\
\text { R, 5'- TTCACCCGGTTGTGGAAACT-3' }\end{array}$ \\
\hline TIMP-1 & $\begin{array}{l}\text { F, 5'- ATATTCTGTCTGGATCGGC-3' } \\
\text { R, 5'- GCTTCGTCACTCCTGTTT-3' }\end{array}$ \\
\hline PDGF & $\begin{array}{l}\text { F, 5'- GGCCTTCTTAAAGATTGGTTCT-3' } \\
\text { R, 5'- GCCTCATAGACCGCACCAAC-3' }\end{array}$ \\
\hline
\end{tabular}


Table 2: Shows serum levels of ALT, AST, ALP, Albumin in the studied groups and not shows serum levels of ALT, AST, ALP, Albumin and Bilirubin (total and direct)

\begin{tabular}{|c|c|c|c|c|}
\hline$\underset{\text { Groups }}{\text { Mean } \pm \text { SD }}$ & $\begin{array}{l}\mathrm{ALT} \\
\mathrm{U} / \mathrm{L}\end{array}$ & $\begin{array}{l}\mathrm{AST} \\
\mathrm{U} / \mathrm{L}\end{array}$ & $\begin{array}{l}\mathrm{ALP} \\
\mathrm{U} / \mathrm{L}\end{array}$ & $\begin{array}{l}\text { Albumin } \\
\mathrm{gm} / \mathrm{dl}\end{array}$ \\
\hline $\begin{array}{l}\text { Control group } \\
(\mathrm{N}=8)\end{array}$ & $21.4 \pm 5.2$ & $27.4 \pm 7.7$ & $135.1 \pm 3.6$ & $4.1 \pm 0.2$ \\
\hline $\begin{array}{l}\mathrm{CCl} 4 \text { group } \\
(\mathrm{N}=8)\end{array}$ & $108.3 \pm 6.2$ & $176.3 \pm 7.9$ & $401.2 \pm 3.2$ & $2.5 \pm 0.19$ \\
\hline $\begin{array}{l}\text { MSCs group } \\
(\mathrm{N}=8)\end{array}$ & $37.64 \pm 3.2$ & $33 \pm 1.9$ & $141.2 \pm 2.6$ & $3.62 \pm 0.21$ \\
\hline $\begin{array}{l}\text { CM group } \\
(\mathrm{N}=8)\end{array}$ & $30.72 \pm 2.3$ & $41.4 \pm 1.2$ & $139.8 \pm 2.1$ & $3.46 \pm 0.42$ \\
\hline P1 & $0.00 * * \mathrm{HS}$ & $0.00 * * \mathrm{HS}$ & $0.00 * * \mathrm{HS}$ & $0.002 *$ \\
\hline $\mathrm{P} 2$ & 0.067 & 0.086 & 0.12 & 0.054 \\
\hline P3 & 0.065 & 0.083 & 0.16 & $0.028^{*}$ \\
\hline P4 & $0.00^{* *} \mathrm{HS}$ & $0.00 * * \mathrm{HS}$ & $0.00 * * \mathrm{HS}$ & $0.00 * * \mathrm{HS}$ \\
\hline P5 & $0.00 * * \mathrm{HS}$ & $0.00 * * \mathrm{HS}$ & $0.00^{* *} \mathrm{HS}$ & $0.00 * * \mathrm{HS}$ \\
\hline
\end{tabular}

P1: $p$ value of T test comparing control group with CCL4 group, P2: $p$ value of T test comparing control group with MSCs group, P3: $p$ value of T test comparing control group with CM group, P4: $p$ value of T test comparing MSCs with CC14 group, P5: $p$ value of T test comparing CM with CCl4 group, *: significant $(p<0.05)$ and $* *$ HS: highly significant $(p<0.001)$.

Table 3: Oxidative stress markers in the studied rat groups

\begin{tabular}{|c|c|c|c|c|c|}
\hline \multirow{2}{*}{ Oxidative stress markers } & \multicolumn{5}{|c|}{ Studied Groups } \\
\hline & Control & CCL4 & MSC & $\mathrm{CM}$ & $P$ value \\
\hline $\begin{array}{l}\text { MDA } \\
\text { (nmol/gm tissue) }\end{array}$ & $49.24 \pm 4.54$ & $123.12 \pm 6.5$ & $52.31 \pm 3.45$ & $53.25 \pm 1.95$ & $\begin{array}{c}\text { P1:0.00** } \\
\text { P2:0.1 } \\
\text { P3:0.07 }\end{array}$ \\
\hline $\begin{array}{l}\text { GSH } \\
\text { (mg/gm tissue) }\end{array}$ & $87.87 \pm 1.13$ & $65.81 \pm 2.19$ & $84.98 \pm 2.72$ & $86.16 \pm 1.52$ & $\begin{array}{c}\text { P1:0.00** } \\
\text { P2:0.07 } \\
\text { P3:0.17 }\end{array}$ \\
\hline $\begin{array}{l}\text { SOD } \\
\text { (U/gm tissue) }\end{array}$ & $8.25 \pm 0.19$ & $4.94 \pm 0.82$ & $7.81 \pm 0.45$ & $7.96 \pm 0.51$ & $\begin{array}{c}\text { P1:0.00** } \\
\text { P2:0.07 } \\
\text { P3:0.19 }\end{array}$ \\
\hline
\end{tabular}

MDA, Malondialdehyde, GSH, reduced glutathione, SOD, superoxide dismutase. Data are presented as means \pm SD. P1: $p$ value of T test comparing control group with CCl4 group, $\mathrm{P} 2: p$ value of T test comparing control group with MSCs group, P3: $p$ value of T test comparing control group with CM group and **: highly significant 
Stem Cells versus Conditioned Media in Liver Fibrosis. Abdel Aal et al.

Table 4: The optical density of hepatocytes glycogen and $\alpha$-SMA and area $\%$ of collagen fibers and in different studied groups (Mean \pm SD).

\begin{tabular}{lccccc}
\hline & Control Group & CCL4 Group & MSC Group & MSCs-CM Group & $P$ value \\
\hline $\begin{array}{l}\text { Optical density of hepatocytes } \\
\text { glycogen }\end{array}$ & $65.1 \pm 1.1$ & $32.2 \pm 3.2$ & $59.2 \pm 1.3$ & $60.1 \pm 2.3$ & $0.00^{* *}$ \\
Optical density of $\alpha$-SMA & $5.2 \pm 1.2$ & $62.1 \pm 2.6$ & $11.3 \pm 0.6$ & $9.25 \pm 0.5$ & $0.00^{* *}$ \\
Area \% of collagen fibers & $1 \pm 0.2$ & $6.5 \pm 1.4$ & $2.3 \pm 0.6$ & $2.1 \pm 0.5$ & $0.00^{* *}$ \\
$P$ value & 0.05 & $0.01^{*}$ & $0.00^{* *}$ & $0.00^{* *}$ & \\
\hline
\end{tabular}

*Statistical significant difference $(P<0.05), * *$ : highly significant

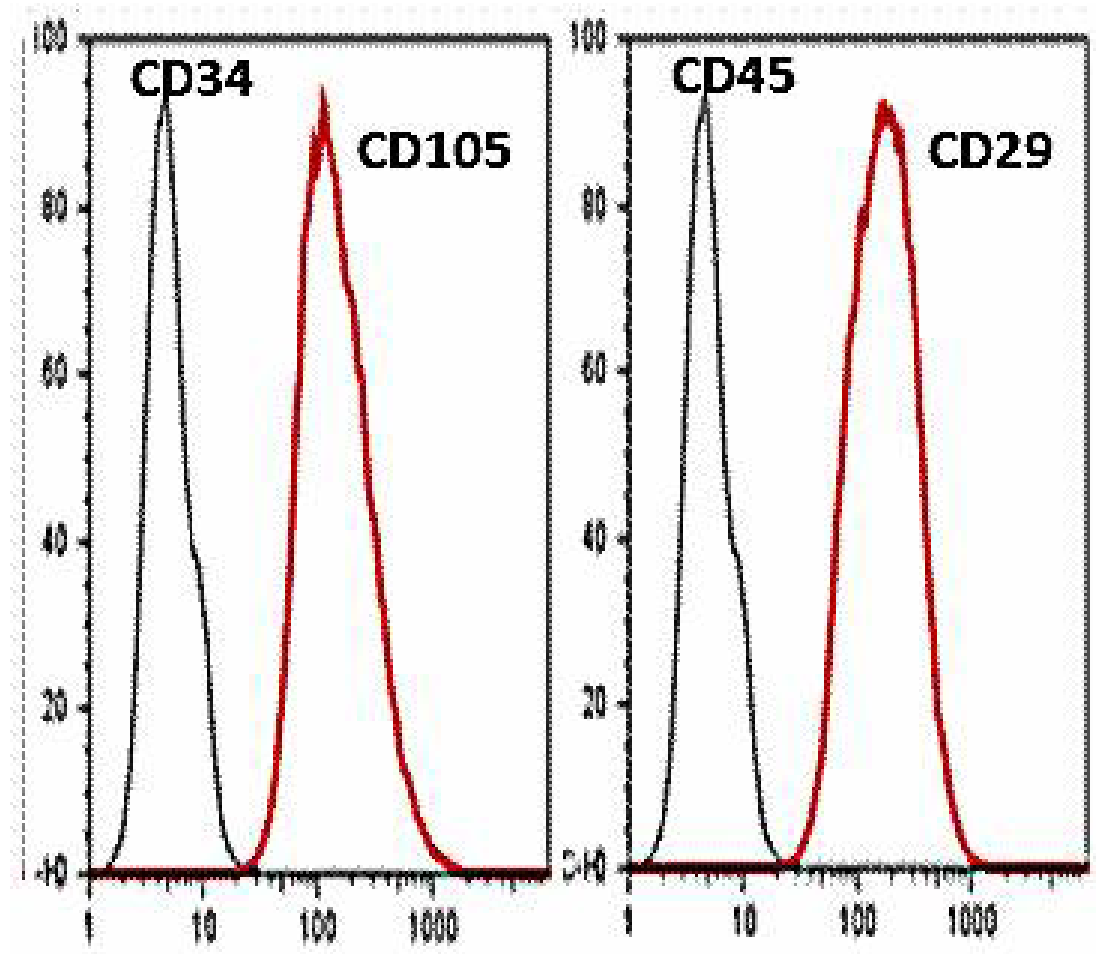

Fig. 1: Flow cytometric analysis picture for characterization of BM-MSCs showing positive mean fluorescence intensity for mesenchymal stem cell markers CD29, and CD105 (red) and negative for CD34 and CD45 (black) which are markers for hematopoietic stem cells. 

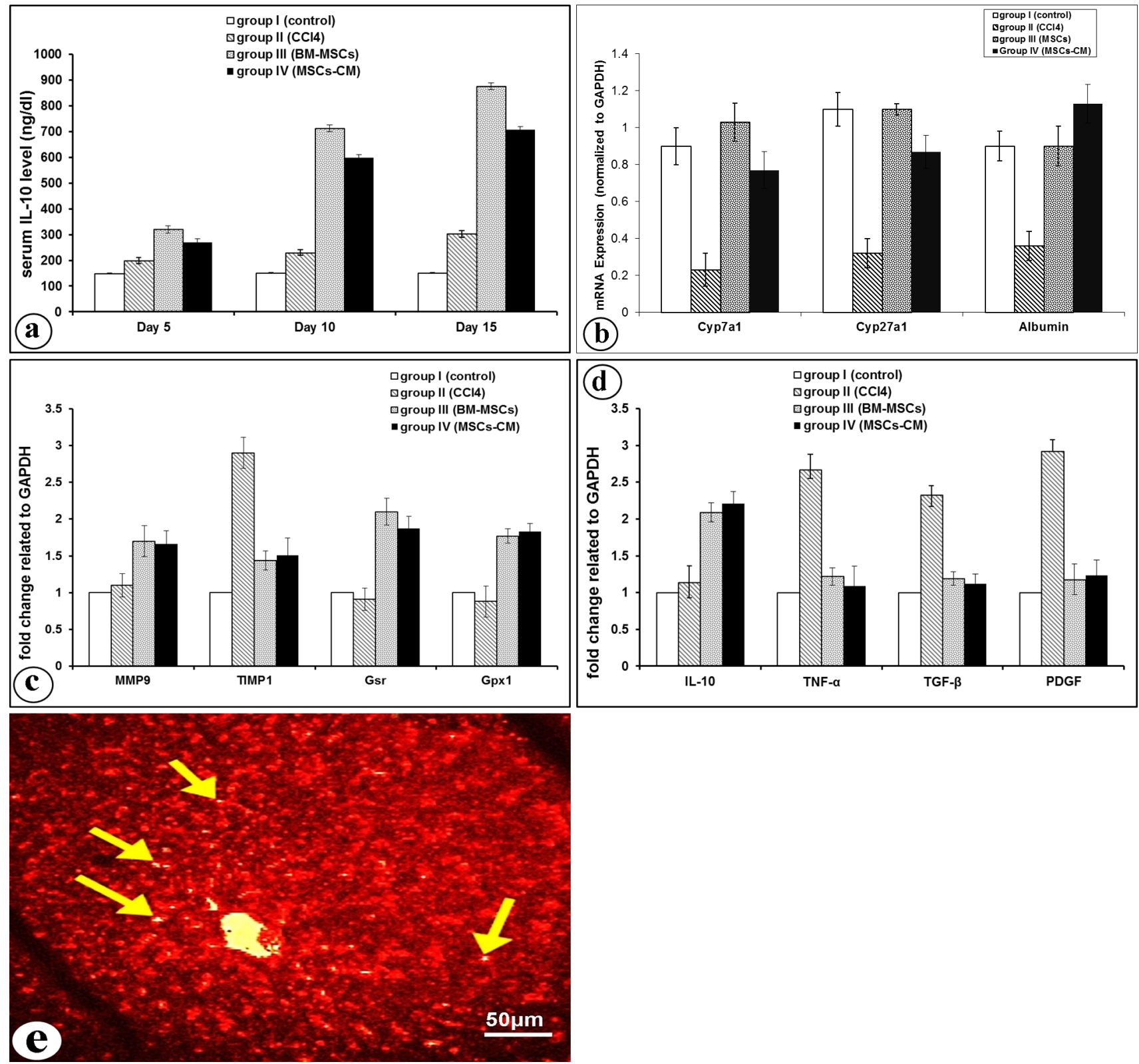

Fig. 2: a: serum interlukin 10 level (ng/dl) in all studied groups at 5,10 and 15 days after transplantation. b: mRNA gene expression of Cyp7a1, Cyp27a1 and Albumin when normalized to GAPDH gene in group I (control), group II (CCl4), group III (BM-MSCs treated) and group IV (CM). c: mRNA gene expression of MMP9, TIMP1, Gsr and Gpx1 when normalized to GAPDH gene in group I (control), group II (CC14), group III (BM-MSCs treated) and group IV (CM). d: mRNA gene expression of IL-10, TNF- $\alpha$, TGF- $\beta$ and PDGF when normalized to GAPDH gene in group I (control), group II (CCl4), group III (BM-MSCs treated) and group IV (CM). e: liver tissue of stem cells-treated group III showing PKH26-labeled stem cells appearing as bright dots (arrows) (Fluorescent Microscope x 200, Scale Bar $50 \mu \mathrm{m}$ ). 

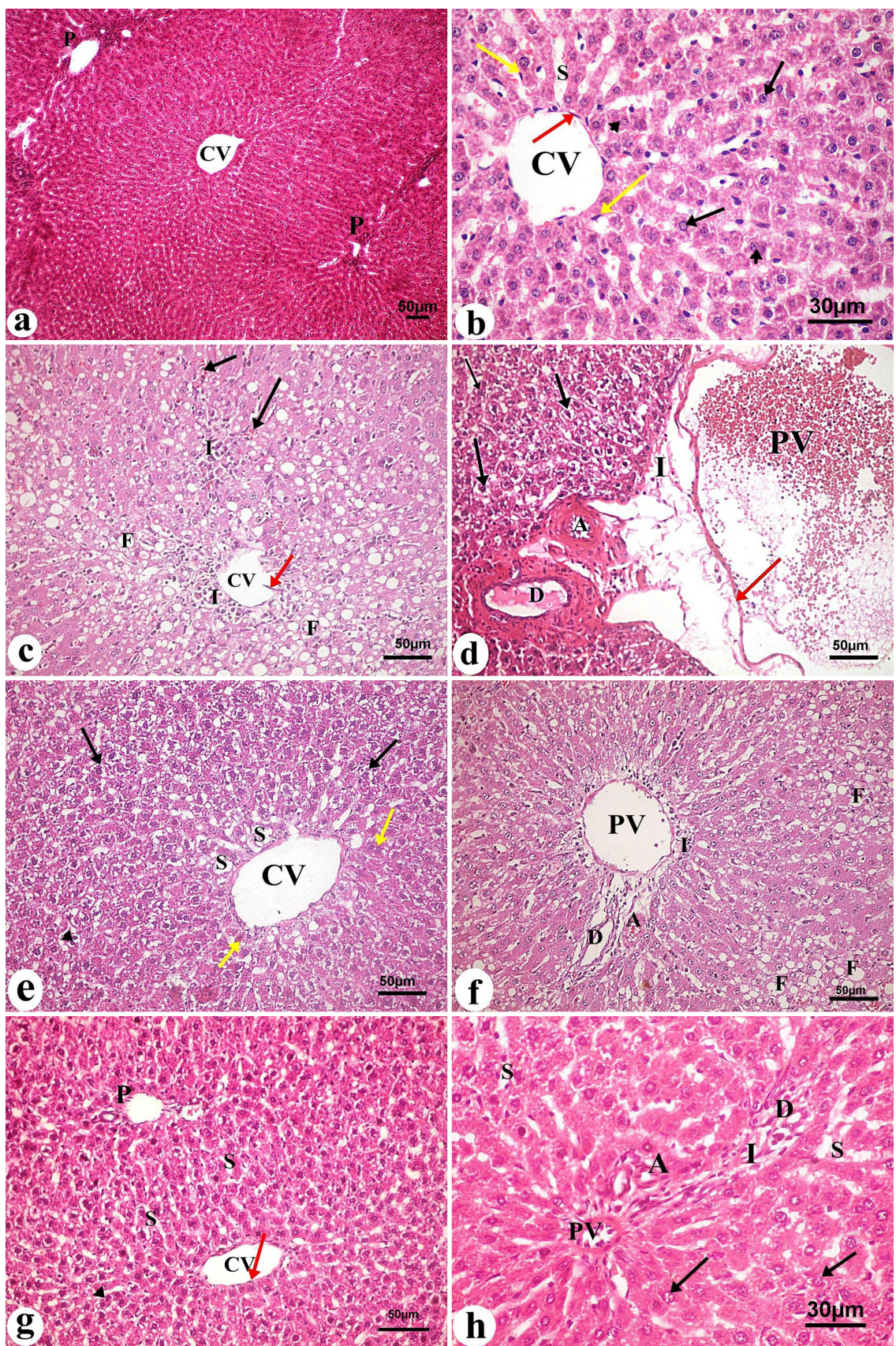

Fig. 3: Haematoxylin and Eosin stained liver sections a: control group shows normal polygonal classic hepatic lobules, hepatocytes are radiating from the central vein (cv), portal areas (P) are seen at the periphery of the lobules. b: the higher magnification shows hepatocytes with vesicular nuclei and acidophilic cytoplasm (arrow), some hepatocytes are binucleated (arrow head). Blood sinusoids (S) are in-between hepatocytic cords. Flat endothelial cells lining sinusoids (yellow arrow) and central vein (red arrow) are seen. CCL4 treated group shows c: detached endothelial lining of central vein (red arrow), cellular infiltration (I), fatty infiltration in-between hepatocytes (F) and congested blood sinusoids (arrow). d: other sections of the same group show most hepatocytes with vacuolated cytoplasm and dark nuclei (thick arrow) others with deep acidophilic cytoplasm (thin arrow), the portal vein is congested and dilated with detached endothelial lining ( red arrow). cellular infiltration (I) can be seen around portal vein, hepatic artery (A) and bile duct (D) can be seen. Stem cells treated group shows e: nearly normal organization of hepatic lobules with dilated sinusoids (S), some cells are vacuolated (arrow), and others with deep acidophilic cytoplasm (yellow arrow), and some cells are binucleated (arrow head). f: the portal area shows dilated portal vein (PV), fatty infiltration (F) and cellular infiltration (I) are evident. MSC-CM treated group shows g: normal organization of hepatic lobules, hepatocytes are radiating from the central vein $(\mathrm{cv})$ which is lined with intact endothelium (red arrow), portal areas (P) are seen at the periphery of the lobules, blood sinusoids (S) are seen between normal shaped hepatocytic cords, some binucleated cells can be seen (arrow head). h: The higher magnification of some sections shows normal shaped portal vein (PV), hepatic artery (A) and bile duct (D) with mild cellular infiltration (I). Most hepatocytes have acidophilic cytoplasm and vesicular nuclei (arrow), with some dilated sinusoids (S) can be seen.

(H\&E: a x10; scale bar $50 \mu \mathrm{m}, \mathrm{b}, \mathrm{h}$ x 40; scale bar $30 \mu \mathrm{m}, \mathrm{c}-\mathrm{g}$ x 20; scale bar $50 \mu \mathrm{m}$ ) 


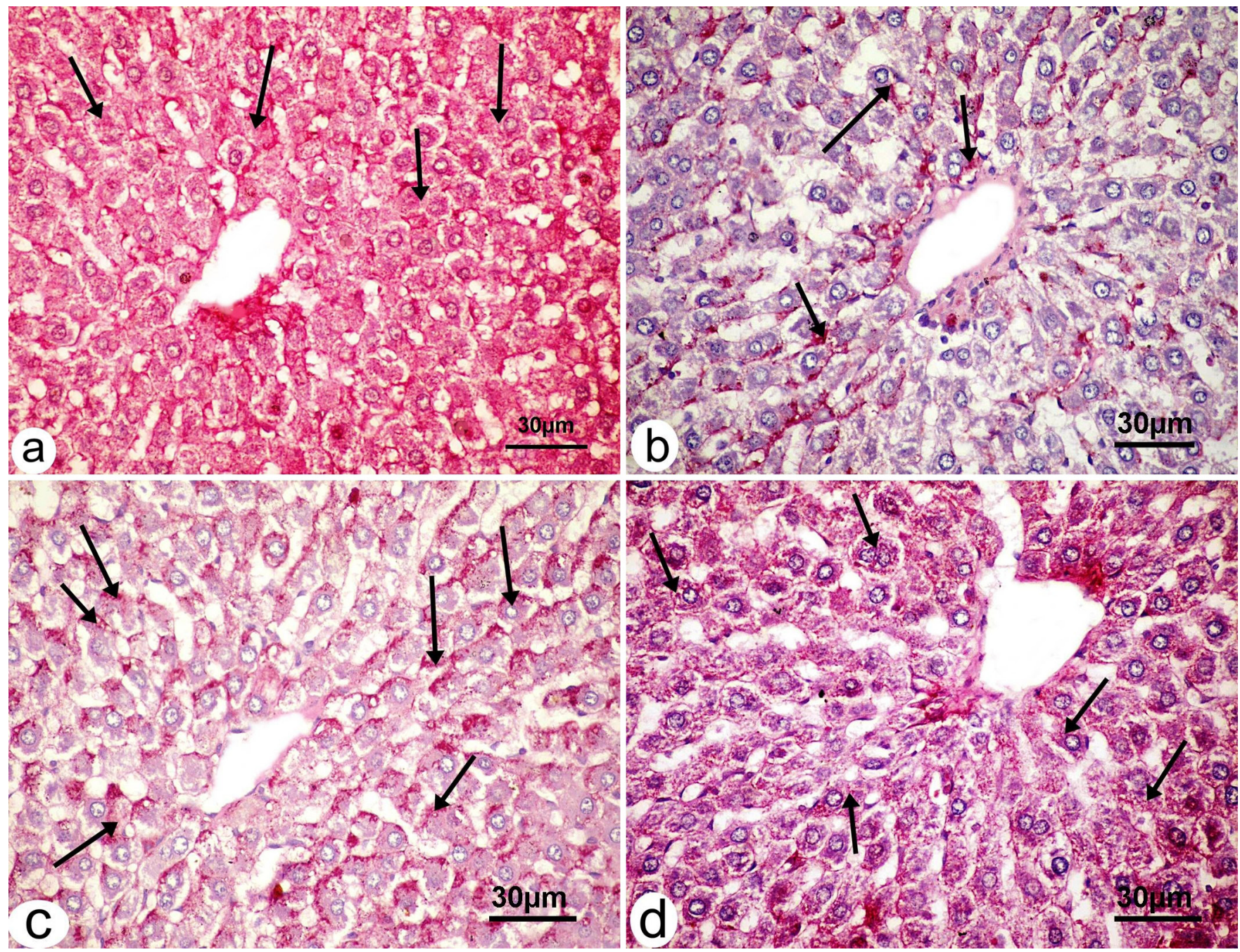

Fig. 4: PAS stained sections showing a: strong positive reaction of glycogen granules in the cytoplasm of hepatocytes in control group (arrows), b: weak positive reaction in group II (arrows), c: positive PAS reaction in some hepatocytes of group III (arrows) and d: strong positive PAS reaction of glycogen granules in the cytoplasm of hepatocytes of group IV(arrows)

(PAS, scale bar $30 \mu \mathrm{m})$ 

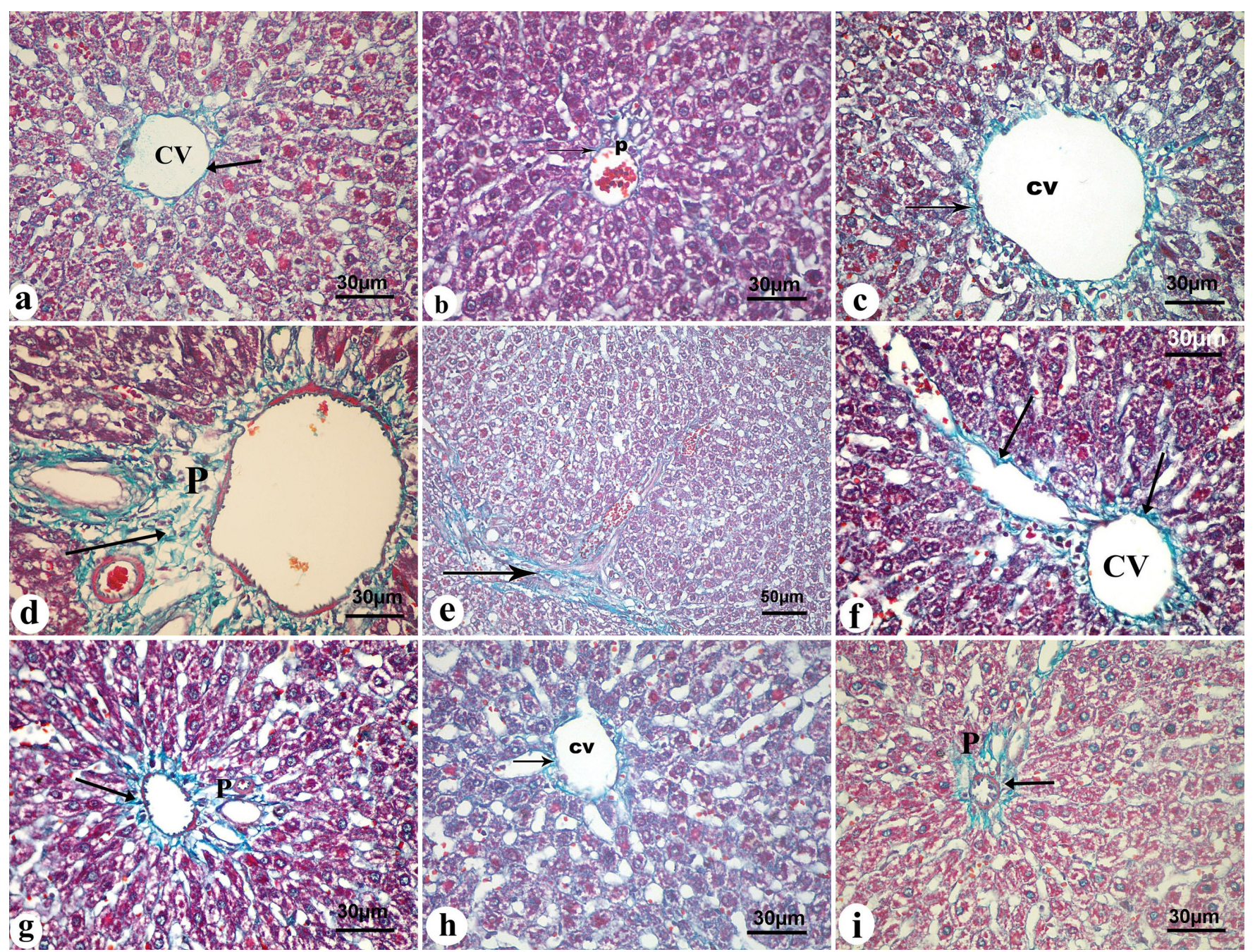

Fig. 5: MT stained sections showing a and b: few collagen fibers around central vein (cv) and portal area (p) in control group (arrow), $\mathrm{c}$ and d: marked increase in collagen deposition around central vein (cv) and portal area (p) and e: bridging fibrosis can also be seen CCL4 treated group. In $\mathrm{f}$ and $\mathrm{g}$ : moderate amount of collagen can be seen in stem cells treated group and $\mathrm{h}$ and $\mathrm{i}$ : show few collagen fibers around central vein (cv) and in portal area (p) in MSC-CM treated group (scale bar 30 $\mu \mathrm{m}$ except fig. 5e $50 \mu \mathrm{m}$ ) 

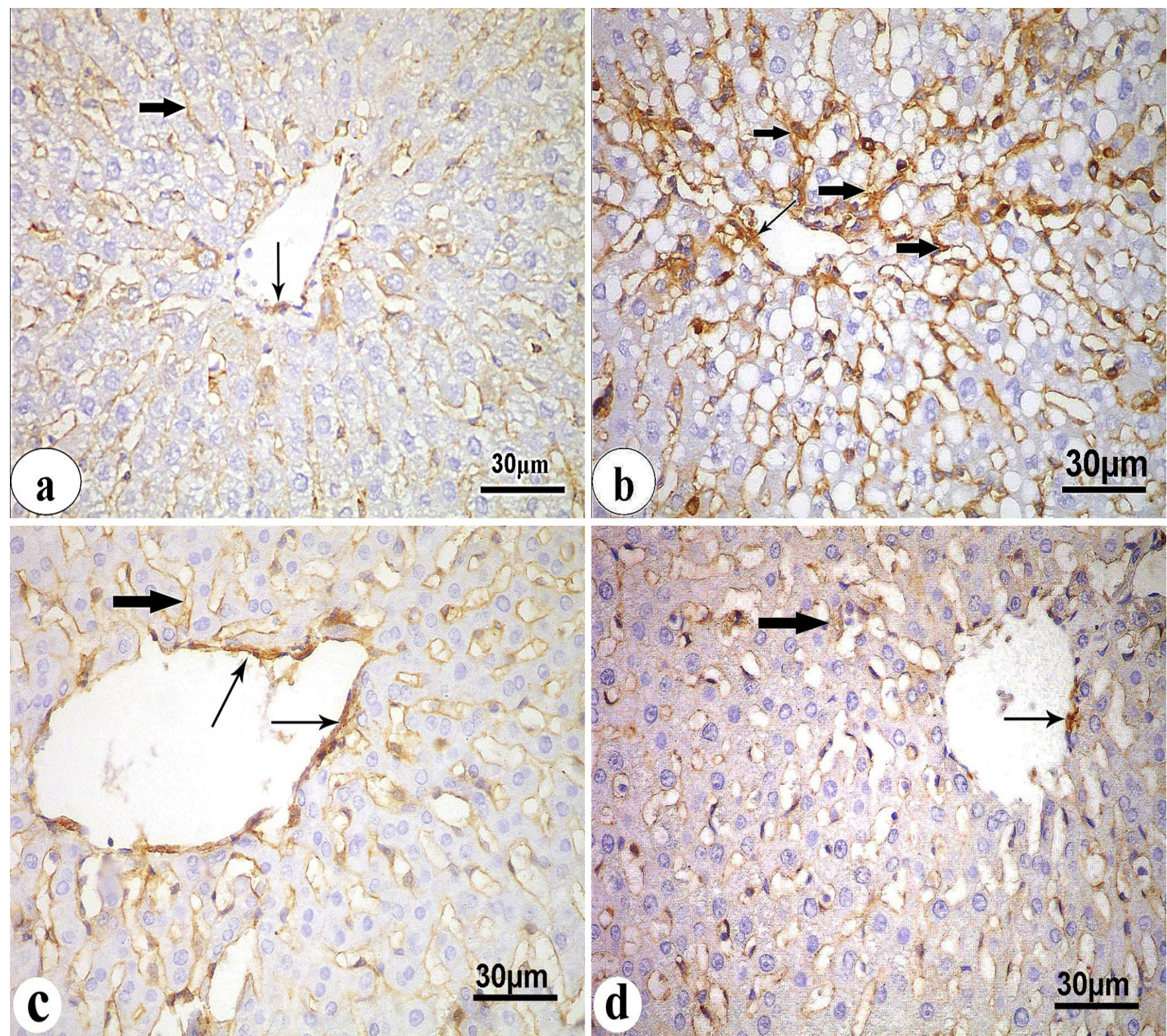

Fig. 6: $\alpha$-SMA immunoreactivity shows a: weak positive immunoreaction in the wall of the central vein (thin arrow) and in-between the hepatocytes (thick arrow) in control group. b: strong positive $\alpha$-SMA immune-reaction in the wall of the central vein (thin arrow) and in-between the hepatocytes (thick arrow) in CCL4 treated group. c: moderate expression of $\alpha$-SMA immune-reaction in the wall of the central vein (thin arrow) and in between the hepatocytes (thick arrow) in MSC-treated group while d: shows weak reaction in MSC-CM treated group. (scale bar $30 \mu \mathrm{m}$ ) 


\section{DISCUSSION}

In our experimental study we used an animal model of liver fibrosis using CCL4 as it is one of the most widely used toxins for induction of liver fibrosis mirroring the pattern of disease in humans according to Hernandez-Gea and Freiedman ${ }^{[29]}$. MSCs were administered by intravenous route as it provides the most effective treatment to prevent fibrosis in contrast to the intra-peritoneal and intra-hepatic injections according to Zhao et al. ${ }^{[30]}$. In the present study we aimed to declare the therapeutic potential of MSCs in comparison to MSCs-CM in liver fibrosis model using CCL4.

In the current study, non-significant changes were noticed in ALT, AST, ALP and albumin levels in MSCs and $\mathrm{CM}$ groups as compared to that in control group. It was reported that transplanted MSCs could renovate the serum albumin level and significantly suppressed transaminase activity and liver fibrosis in the injured liver of rats ${ }^{[10,31]}$.

Lipid peroxidation and final cell death have been reported as a major contributor to the loss of cell function under oxidative stress conditions ${ }^{[32]}$. SOD is a major antioxidant defense that protects tissues within the body from oxidative stress ${ }^{[33]}$. Moreover, SOD secreted by MSCs decreases ROS in injured liver cells. We suggest that MSCs may protect against CCL4-induced injury by altering the oxidative microenvironment of the liver at the site of engraftment. MSCs could secrete many cytokines and growth factors ${ }^{[34]}$, which show anti-apoptotic activity in hepatocytes and play an essential part in liver regeneration ${ }^{[35]}$.

Production of bile acids from cholesterol is principally regulated by two key enzymes, namely microsomal cholesterol $\alpha$-hydroxylase (CYP7A1) and mitochondrial sterol 27-hydroxylase (CYP27A1) ${ }^{[36]}$ which are improved in MSCs and CM groups. These improvements were referred to the repairing of the damaged hepatocytes and resolution of fibrosis.

Histological and immunohistochemical observations provided supportive evidence for those biochemical results as light microscopic examination of MSCs group rats revealed remarkable improvement of the liver structure. Most of the hepatocytes appeared nearly similar to that of the control rats with an acidophilic cytoplasm and vesicular nuclei. Dilated portal vessels were observed and in some areas they were congested, yet these changes were moderate as compared to the fibrotic group.

Histological examination of CCL4 treated group showed different forms of hepatic lobular affection in the form of detached endothelial lining of central vein, congested blood sinusoids and congested portal vein. These findings were attributed to portal hypertension or to the direct effect of CCL4 on the vascular endothelial cells leading to release of endothelium relaxation factornitric oxide ${ }^{[37]}$. Another explanation was introduced by Saadoun et al. ${ }^{[38]}$ and Puche et al. ${ }^{[39]}$ who attributed sinusoidal dilatation to the activation of peri-sinusoidal cells that have contractile properties.

Most hepatocytes showed vacuolated cytoplasm and dark nuclei but some cells still have deep acidophilic cytoplasm. It is strongly believed that all toxic effects of CCL4 are related to its biotransformation by CYP2E1 into more destructive trichloromethylperoxy radical (CCl3OO) in the presence of oxygen ${ }^{[40]}$. It is well known that a single dose of CCL4 leads to the occurrence of centrizonal necrosis and steatosis, while prolonged CCL4 administration leads to liver fibrosis, cirrhosis, and hepatocellular carcinoma $(\mathrm{HCC})^{[41]}$.

Cellular and fatty infiltration in-between hepatocytes were also evident. This inflammatory reaction could be related to oxidative stress that resulted in generation of mediators such as IL-8 and cytokine-induced neutrophil chemo attractant which attract the inflammatory cells into microcirculation and then to the liver interstitium due to destruction of the endothelial cells by the free radicals ${ }^{[42,43]}$. In response to inflammation, $\mathrm{HpSCs}$ are activated into myofibroblasts and proliferated by the action of $\mathrm{TGFb}$ and PDGF respectively, that are secreted by macrophages ${ }^{[44,45]}$.

Masson trichrome stained sections showed marked increase in collagen deposition around central vein and portal area. Liver fibrosis results from chronic injury to the liver in conjunction with excessive deposition of collagen and other components of the extracellular matrix (ECM), which is a characteristic of most types of chronic liver diseases ${ }^{[46]}$. The generation of ROS has an important role in the damage of the liver by enhancing the production of pro-fibrogenic mediators and so initiating hepatic fibrogenesis ${ }^{[4]}$.

Strong positive $\alpha$-SMA immune-reaction was observed in the wall of the central vein and in-between the hepatocytes in CCL4 treated group. Cheung et al. ${ }^{[47]}$ mentioned that, $\alpha$-SMA is a marker for the activity of hepatic stellate cells (HpSCs), which are the primary cell type that mediate fibrogenesis. In response to inflammation, HpSCs are activated into myofibroblasts and proliferated by the action of TGFb and PDGF, respectively, secreted by macrophages ${ }^{[44,45]}$.

H\&E stained sections of Stem cells treated group showed nearly normal organization of hepatic lobules with dilated sinusoids, some cells showed vacuolations, and others with deep acidophilic cytoplasm. Dilated portal vein, cellular and fatty infiltrations were evident. Positive PAS reaction was observed in some hepatocytes of MSC-treated group. Moderate expression of $\alpha$-SMA immunoreaction was also detected in the wall of the central vein and in between 
the hepatocytes. Also, statistically significant increase in optical density of hepatocyte glycogen and significant decrease in optical density of $\alpha$-SMA was observed in the same group as compared to control in the present study.

These findings were in agreement with Abdel Aziz et al. ${ }^{[48]}$ who described reduction in fibrosis and ALT level with albumin improvement in rats by transplanting MSC. Baligar et al. ${ }^{[49]}$ mentioned that, macrophages are considered master regulators in both progression and resolution of liver fibrosis. MSCs mediate a switch from pro-inflammatory M1-type macrophages to anti-inflammatory M2-type macrophages ${ }^{[50]}$.

El-khayat et al. ${ }^{[51]}$ also reported that, MSCs have anti fibrotic effect evidenced by the disappearance of septal collagen deposition and diffuse and homogeneous PAS staining for glycogen in their study. Ries et al. ${ }^{[52]}$ suggested that lysis of fibrotic tissue was accomplished by MSCs-secreted MMP2 that promote the degradation of ECM in liver cirrhosis. MMPs, especially MMP-9, have the potential to reverse the fibrotic process by inhibiting collagen deposition, transforming growth factor- $\beta 1$ production, directly degrade the extracellular matrix and lead to hepatic stellate cell apoptosis ${ }^{[53]}$.

Thus, we assayed for mRNA expression differences of some cytokines and interleukins that play an important role in fibrosis progression. PDGF expression, that enhances liver fibrosis via stimulation of hepatic stellate cells expressing collagen and TIMP, was decreased in response to stem cells or culture medium ${ }^{[54]}$.

TNF $\alpha$ and TGF $\beta$ were expressed at significantly lower levels in MSCs and CM groups. However, IL10 was highest in those groups. These results demonstrate that IL10 expression may play a central role in mediating the greater effects of intravenously injected MSCs in ameliorating liver fibrosis. IL10 is a key player in the regulation of the Th1-mediated immune response and homeostasis between matrix metalloproteinase and the tissue inhibitors of the MMP. IL10 is an inhibitor of many cytokines that stimulate tissue fibrosis, such as IL6, TNF $\alpha$ and TGF $\beta$. In addition, IL10 can suppress TIMP-1 expression and thereby relieve MMP-1 to degrade liver collagen deposits. HSC apoptosis can also be triggered by MSC-secreted nerve growth factor (NGF) stimulation ${ }^{[5,56,57]}$.

According to previous reports, an intravenous injection of MSCs can beneficially modulate the host immune response by increasing the release of prostaglandin E2 from the BM-derived MSCs acting on the EP2 and EP4 receptors of the macrophages and by stimulating the production and release of IL10 $0^{[58]}$.

On the other hand, Carvalho et al. ${ }^{[12]}$ reported no improvement of fibrosis following MSCs transplantation in rats. It could be explained by its effect on macrophages as, in fibrosis regression, the infiltrating macrophages adopt fibrolytic phenotypes to secrete metalloproteinases (MMP-9, 12, 13) for degradation of excess ECM components. Meanwhile, MSC transplantation, suppressed the recruitment of these macrophages in fibrotic liver, resulting in an incomplete degradation of $\operatorname{scar}^{[44,59]}$. In addition, MSC transplantation did not improve tissue level MMP-9 and 13 gene expression in the study of Cawston and Young ${ }^{[60]}$. MSC infusion was found to accelerate the progress of fibrosis via the conversion of MSCs into fibrous scar-producing myofibroblasts ${ }^{[61]}$.

Another explanation according to Baligar et al ${ }^{[49]}$ is that, many factors such as vascular endothelial growth factor, TGFb, PDGF, and IGF-1 are secreted by MSCs and can protect hepatic stellate cells (HpSCs) from undergoing apoptosis, induce myofibroblastic differentiation, and proliferation. TGF- $\beta 1$ has also been shown to affect pathogenesis of idiopathic pulmonary fibrosis due to fibroblast to myofibroblast differentiation and the Epithelial To Mesenchymal Transition (EMT) ${ }^{[62,63]}$.

MSC-CM treated group showed normal organization of hepatic lobules, central vein was lined with intact endothelium, blood sinusoids were seen between normal shaped hepatocytic cords and some binucleated cells could be seen. Our findings are in agreement with ${ }^{[64]}$ who reported that intravenous bolus of MSC-CM during active disease can reverse organ failure. They also observed marked reduction in mononuclear leukocytic infiltration, prevention of hepatocyte apoptosis and inhibition of bile duct duplication after MSC-CM treatment. Huang et al. ${ }^{[65]}$ also found that MSC and MSC-CM infusion similarly stimulated liver regeneration and suppressed hepatocelluar death in mice with acute and chronic liver failure.

According to Van Poll et al. ${ }^{[66]}$, low-concentrations of MSC-CM are sufficient to promote hepatocelluar proliferation and inhibition of hepatocyte apoptosis. Huang et al. ${ }^{[65]}$ added that, MSC-CM includes small amounts of inhibitory components, such as TNF- $\alpha$ and TGF- $\beta$, whose negative effects at higher concentrations offset the therapeutic effects of trophic factors.

It has been demonstrated that MSC-CM has direct antiapoptotic and pro-mitotic effects on cultured hepatocytes. Furthermore, it inhibited death of hepatocytes and enhanced the liver regeneration in vivo and improved survival in rats after D-galactosamine-induced fulminant hepatic failure ${ }^{[6]}$. Various cytokines were secreted by stem cells into the CM. Such cytokines are grouped into growth factors, pro-inflammatory and anti-inflammatory cytokines $^{[67]}$.

In the present study, few collagen fibers were detected around central vein and in portal area in MSC-CM treated group together with weak immunoreaction of $\alpha$-SMA. 
Samad et al. ${ }^{[68]}$ proved that MSC-CM has anti-fibrotic effects with the ability to modulate the fibroblast to myofibroblast differentiation process. They added, MSC$\mathrm{CM}$ can inhibit TGF- $\beta 1$ induced differentiation process and also de-differentiate myofibroblasts. Furthermore MSC have been shown to secrete FGF, PGE and PDGF. Therefore it is possible that these growth factors were evident within MSC-CM and responsible for the dedifferentiate effects ${ }^{[69]}$

In vitro experiments of Baligar et al. ${ }^{[49]}$ showed that MSCs-CM promotes apoptosis in HpSCs. Such apoptotic effect may be due to the action of death ligands present in the CM, which are potentially secreted by NK cells and fibrolytic macrophages ${ }^{[70]}$.

MSCs-CM has the advantage of mass production by pharmaceutical companies ${ }^{[67]}$. Conditioned media are not like stem cells that need a good manufacturing practice (GMP) facility to be applied to patients ${ }^{[71]}$. Unlike stem cells, CM can be transported easily as drugs and does not need cryopreservation. However, CM needs to be given more frequently, as cytokines' and growth factors' halflives are mostly shorter ${ }^{[72,73]}$.

\section{CONCLUSION}

BM-MSCs conditioned medium shows a predominant therapeutic role in experimentally-induced chronic liver fibrosis as compared to BM-MSCs. This was evidenced by improved morphological, immunohistochemical and biochemical measures in the present study. Future studies should be carried out to more delineate the mechanisms underlying their action.

\section{ABBREVIATION}

Stem cell conditioned media (CM), Bone marrow derived mesenchymal stem cells (BM-MSCs), Carbon tetrachloride (CCL4), Real-time polymerase chain reaction (RT-PCR), Enzyme linked immunosorbent assay (ELISA), Hepatitis B virus (HBV), Hepatitis C virus (HCV), Hepatic stellate cell (HSC), extracellular matrix (ECM), Dulbecco's modified Eagle's medium (DMEM), Phosphate buffered saline (PBS), Serum alanine transaminase (ALT), Aspartate transaminase (AST), Alkaline phosphatase (ALP), Malondialdehyde (MDA), Reduced glutathione (GSH), Superoxide dismutase enzyme activity (SOD), alpha smooth muscle actin ( $\alpha$-SMA), Immunoglobulin G (IgG), Periodic acid Schiff (PAS), Masson Trichrome (MT) staining, Trichloromethylperoxy radical (CCl3OO), Hepatocellular carcinoma (HCC), Epithelial To Mesenchymal Transition (EMT).

\section{CONFLICT OF INTEREST}

There are no conflicts of interest.

\section{REFERENCES}

1. Motawi, T., Atta, H., Sadik, $\mathrm{N}$ and Azzam, M. (2014) The Therapeutic Effects of Bone Marrow-Derived Mesenchymal Stem Cells and Simvastatin in a Rat Model of Liver Fibrosis. Cell BiochemBiophys. 68,111-125.

2. Abdel Aziz, M., Atta, H., Roshdy, N., Rashed, L., Sabry, D., Hassouna, A., AboulFotouh, G., Hasan, N., Younis, R. and Chowdhury, J. (2012) Amelioration of murine schistosoma mansoni induced liver fibrosis by mesenchymal stem cells. Journal of Stem Cells and Regenerative Medicine. 8:28-34.

3. Poynard, T., Yuen, M.F., Ratziu, V. and Lai, C.L. (2003) Viral hepatitis C. Lancet. 362: 2095-2100.

4. Friedman, S.L. (2008) Mechanisms of hepatic fibrogenesis. Gastroenterology. 134: 1655-1669

5. Basto, S., Ribeiro, J., Perez, R., et al. (2007) Liver transplantation waiting list mortality and its characteristics in a Brazilian center. Liver Transpl, 13(Suppl. 1): 177.

6. Zheng, F. and Liang, J. (2009) Intra-portal transplantation of bone marrow stromal cells ameliorates liver fibrosis in mice. Hepatobiliary Pancreat. Dis. Int. 7(3): 264-270.

7. Parekkadan, B., Van Poll, D., Suganuma, K., Carter, E.A., Berthiaume, F., Tilles, A.W. and Yarmush, M.L. (2007) Mesenchymal stem cellderived molecules reversefulminant hepatic failure. PLoS One. 2: e941.

8. Fang, B., Shi, M., Liao, L., Yang, S., Liu, Y. and Zhao, R.C. (2004) Systemic infusion of FLK1(+) mesenchymal stem cells ameliorate carbon tetrachloride-induced liver fibrosis in mice. Transplantation. 78: 83-88.

9. Gholamrezanezhada, A., Mirpoura, S., Bagherib, M., Mohamadnejadb, M., Alimoghaddamc, K., Abdolahzadehb, L., Sagharia, M. and Malekzadehb, R. (2011) In vivo tracking of 111 Inoxine labeled mesenchymal stem cells following infusion in patients with advanced cirrhosis. Nuclear Medicine and Biology. 38: 961-967. 
10. Nasir, A., Mohsin, S., Mohsin, Shams, S., Ali, G., Khan, S. and Riazuddin, S. (2013) Mesenchymal stem cells and Interleukin-6attenuate liver fibrosis in mice. Journal of Translational Medicin. 11: 78.

11. Raafat, N., Abdel Aal, S., Abdo, F. and El Ghonaimy, N. (2015) Mesenchymal stem cells, In vivo therapeutic application ameliorates carbon tetrachloride induced liver fibrosis in rats. The International Journal of Biochemistry and Cell Biology. 68: 109-118.

12. Carvalho, A.B., Quintanilha, L.F., Dias, J.V., Paredes, B.D., Mannheimer, E.G., Carvalho, F.G., Asensi, K.D., Gutfilen, B., Fonseca, L.M., Resende, C.M., Rezende, G.F. (2008) Bone marrow multipotent mesenchymal stromal cells do not reduce fibrosis or improve function in a rat model of severe chronic liver injury. Stem cells. 26(5):1307-14.

13. Quintanilha, F., Mannheimer, E. and Carvalho, A. (2008) Bone marrow cell transplant does not prevent or reverse murine liver cirrhosis. Cell Transplant. 17: 943.

14. Manibusan, M., Odin, M. and Eastmond, D. (2007) Postulated carbon tetrachloride mode of action, a review. J Environ Sci Health C Environ Carcinog Ecotoxicol Re. 25:185-209.

15. Mohammed, N.R., Ahmed, R.H., Roshdy N.K., Aref, M.I., Hassan, N.M. and Saleh, H.E. (2014) Effect of Bone Marrow-derived Mesenchymal Stem Cells and Umbilical Cord Blood-CD34+ cells on Experimental Rat liver Fibrosis. Int J Stem Cell Res Transplant. 02(03): 63-68.

16. Fujii, T., Fuchs, B., Yamada, S., Lauwers, G., Kulu1, Y.,Goodwin, J., Lanuti, M. and Tanabe, K. (2010) Mouse model of carbon tetrachloride induced liver fibrosis, Histopathological changes and expression of CD133 and epidermal growth factor. BMC Gastroenterology. 10: 79.

17. Fox, J.M., Chamberlain, G., Ashton, B.A. and Middleton, J. (2007) Recent advances into the understanding of mesenchymal stem cell trafficking. Br J Haematol. 137: 491-502.

18. Kim, H. O. and Choi, S. (2013) Mesenchymal stem cell-derived secretome and microvesicles as a cell-free therapeutics for neurodegenerative disorders. Tissue Engineering and Regenerative Medicine. 10(3): 93-101.
19. Kara A, Unal D, Simsek N, Yucel A, Yucel N et al. (2014) Ultra-structural changes and apoptotic activity in cerebellum of postmenopausaldiabetic rats: a histochemical and ultra-structural study. J Gynecol Endocrinol 30: 226-231.

20. Haas, S.J., Bauer, P., Rolfs, A. and Wree A. (2000) Immunocytochemical characterization of in vitro PKH26-labelled and intracerebrally transplanted neonatal cells. Acta Histochem. 102: 273-280.

21. Tietz, N.W., (1995) Clinical Guide to Laboratory Tests. WB Saunders Company, Philadelphia, PA, pp. 518-522.

22. Ohkawa, H., Ohishi, N., Yagi, K. (1979) Assay for lipid peroxides in animal tissues by thiobarbituric acid reaction. Anal Biochem. 95 (2): 351-358.

23. Beutler, E., Duron, O., Kelly, B.M., (1963) Improved method for the determination of blood glutathione. J. Lab. Clin. Med. 61:882-888.

24. Aebi, H., (1974) Catalase. In, Bergmeyer H.U., editor. Methods of Enzymatic Analysis. Academic Press, New York, NY, USA. pp. 673-677.

25. Bancroft, J. and Gamble, A. (2008) Theory and Practice of Histological Techniques, 6th ed. Churchill Livingstone, New York, London. pp. 165-175.

26. Ramos-Vara, J.A., Kiupel, M., Baszier, T., Bliven, L., Brodersen, B., Chelack, B. et al. (2008) Suggested guidelines for immunohistochemical techniques in veterinary diagnostic laboratories. J. Vet. Diagn. Invest. 20: 393-413

27. Barry F, Boynton R, Haynesworth S. (1999) The monoclonal antibody SH-2, raised against human mesenchymal stem cells, recognizes an epitope on endoglin (CD105). BiochemBiophys Res Commun. 265: 134e9.

28. Conget P and Minguell J. (1999) Phenotypical and functional properties of human bone marrow mesenchymal progenitor cells. J Cell Physiol. 181: 67-73.

29. Hernandez-Gea, V. and Freiedman, S.L. (2011). Pathogenesis of liver fibrosis. Annu. Rev. Pathol. 6: 425-456.

30. Zhao, W., Li, J., Cao, D., Zhang, L., He, Y., Yue, 
S., Wang, D. and Dou, K. (2012) Intravenous injection of mesenchymal stem cells is effective in treating liver fibrosis. World $\mathrm{J}$ Gastroenterol. 18(10): 1048-1058.

31. Oyagi, S., Hirose, M., Kojima, M., Okuyama, M., Kawase, M., Nakamura, T., Ohgushi, H. and Yagi, K. (2006) Therapeutic effect of transplanting HGF-treated bone marrow mesenchymal cells into CCl4-injured rats. J. Hepatol. 44: 742-748.

32. Storey, K. (1996) Oxidative stress, animal adaptations in nature. Brazilian Journal of Medical and Biological Research. 29: 1715-1733.

33. Salvemini, D. and Cuzzocrea, S. (2003) Therapeutic potential of superoxide dismutase mimetics as therapeutic agents in critical care medicine. Crit. Care Med. 31: S29-S38.

34. Matsuda-Hashii, Y., Takai, K., Ohta, H., Fujisaki, H., Tokimasa, S., Osugi, Y., et al. (2004) Hepatocyte growth factor plays roles in the induction and autocrine maintenance of bone marrow stromal cell IL-11, SDF-1 alpha, and stem cell factor. Exp. Hematol. 32: 955-961.

35. Ueki, T., Kaneda, Y., Tsutsui, H., Nakanishi, K., Sawa, Y., Morishita, R., Matsumoto, K., Nakamura, T., Takahashi, H., Okamoto, E., Fujimoto, J. (1999) Hepatocyte growth factor gene therapy of liver cirrhosis in rats. Nat. Med. 5(2): 226-30.

36. Vlahcevic, Z.R., Pandak, W.M., Heuman, D.M., Hylemon, P.B. (1992) Function and regulation of hydroxylases involved in the bile acid biosynthesis pathways. Semin. Liver Dis. 12: 403-419.

37. Hu, L.S., George, J. and Wang, J.H. (2013) Current concepts on the role of nitric oxide in portal hypertension. World J. Gastroentrol. 19: 1707-1717.

38. Saadoun, D., Cazal, S., Hatem, D., Denninger, M.H., Boudaoud, L., Pham, B.N., Mallet, V., et al. (2004) Association of idiopathic hepatic sinusoidal dilatation with the immunological features of the antiphospholipid syndrome. Gut 53: 1516-1519.

39. Puche, J., Saiman, Y., Friedman, S. (2013) Hepatic stellate cells and liver fibrosis. Compr. Physiol. 3: 1473-1492

40. Wong, F.W., Chan, W.Y., Lee, S.S. (1998) Resistance to carbon tetrachloride induced hepatotoxicity in mice which lack CYP2E1 expression. Toxicol App Pharmacol. 153: 109-118.

41. Mohammed, A., Abd Al Haleem, E.N., El-Bakly, W.M., El-Demerdash. E. (2016) Deferoxamine alleviates liver fibrosis induced by $\mathrm{CCl} 4$ in rats. Clinical and Experimental Pharmacology and Physiology. 43(8): 760-768.

42. Rahman, I. and Mcnee, W. (2000) Oxidative stress and regulation of glutathione in lung reduce fibrosis or improve function in a rat model of severe chronic liver injury. Stem cells. 26: 1307-1314.

43. Aydin, G., Ekrem, I., Mehmet, A. and Osman, G. (2003) Histopathological and Biochemical Changes in Lung Tissues of Rats Following Administration of Fluoride over Several Generations. J. Appl. Toxicol. 23: 437-446.

44. Frank, T., Henning, W.Z. (2014) Macrophage heterogeneity in liver injury and fibrosis. J Hepatol. 60: 1090-1096.

45. Lucia A.P., Mark, R.T., Julia, A.W. et al. ((2014) Modulation of monocyte/ macrophage function, A therapeutic strategy in the treatment of acute liver failure. J Hepatol. 61: 439-445.

46. Friedman SL. Mechanisms of hepatic fibrogenesis. Gastroenterology (2008); 134: 1655-1669

47. Cheung, P.Y., Zhang, Q., Zhang, Y.O., Bai, G.R., Lin, M.C., Chan, B., (2006) Effect of WeiJia on carbon tetrachloride induced chronic liver injury. World J. astroenterol. 12: 1912-1917. DOI 10.1186/s12967-016-0792-1

48. Abdel Aziz, M.T., Atta, H.M., Mahfouz, S. et al. (2007) Therapeutic potential of bone marrowderived mesenchymal stem cells on experimental liver fibrosis. Clin Biochem.40: 893-899

49. Baligar, P., Mukherjee, S., Kochat, V., Rastogi, A., Mukhopadhyay, A. (2016) Molecular and cellular functions distinguish superior therapeutic efficiency of bone marrow CD45 cells over mesenchymal stem cells in liver cirrhosis. Stem Cells. 34(1): 135-47.

50. Prockop, D.J., Oh, J.Y. (2011) Mesenchymal stem/stromal cells (MSCs), role as guardians of inlammation. Mol Ther. 20: 14-20.

51. El-Khayat, Z.A., Mostafa, E.H., Hussein J.I., El- 
waseef, M.A., Farrag, L.R., Medhat, D. (2013) Mesenchymal stem cells therapy for thioacetamide induced liver cirrhosis. Int. J. Pharm. Pharm. Sci. 5: 196-203.

52. Ries, C., Egea, V., Karow, M., Kolb, H., Jochum, M., Neth, P. (2007) MMP-2, MTIMMP. and TIMP-2 are essential for the invasive capacity of human mesenchymal stem cells, differential regulation by inflammatory cytokines. Blood 109: 4055-4063

53. Tsai, P.C., Fu, T.W., Chen, Y.M.A. et al. (2009) The therapeutic potential of human umbilical mesenchymal stem cells from Wharton's jelly in the treatment of rat liver fibrosis. Liver Transplantation 15 (5): 484-495.

54. Adachi, T., Togashi, H., Suzuki, A., Kasai, S., Ito, J., Sugahara, K., Kawata, S. (2005) $\mathrm{NAD}(\mathrm{P}) \mathrm{H}$ oxidase plays a crucial role in PDGF induced proliferation of hepatic stellate cells. Hepatology. 41: 1272-1281

55. Chen, X., Li, Y., Wang, L., Katakowski, M., Zhang, L., Chen, J., Xu, Y., Gautam, S.C., Chopp, M. (2002) Ischemic rat brain extracts induce human marrow stromal cell growth factor production. Neuropathol. 22: 275-279.

56. Zheng, W.D., Zhang, L.J., Shi, M.N., Chen, Z.X., Chen, Y.X., Huang, Y.H., Wang, X.Z. (2005) Expression of matrix metalloproteinase-2 and tissue inhibitor of metalloproteinase- 1 in hepatic stel-late cells during rat hepatic fibrosis and its intervention by IL-10. World $\mathrm{J}$ Gastroenterol. 11: 1753-1758

57. Zhang, L.J., Yu, J.P., Li, D., Huang, Y.H., Chen, Z.X., Wang, X.Z. (2004) Effects of cytokines on carbon tetrachloride-induced hepatic fibrogenesis in rats. World J Gastroenterol. 10: 77-81.

58. Németh K, Leelahavanichkul A, Yuen PS, Mayer B, Parmelee A, Doi K, Robey PG, Leelahavanichkul $\mathrm{K}$, Koller BH, Brown JM, et al. (2009) Bone marrow stromal cells attenuate sepsis via prostaglandin E (2)-dependent reprogramming of host macrophages to increase their interleukin-10 production. Nat Med. 15: 42-49.

59. Akihiro, S., Yoshio, S., Takuya, K. et al. (2013) Adipose tissue-derived stem cells as a regenerative therapy for a mouse steatohepatitis-induced cirrhosis model. Hepatology. 58: 1133-1142.

60. Cawston, T.E., Young, D.A. (2010) Proteinases involved in matrix turnover during cartilage and bone breakdown. Cell Tissue Res. 339: 221-235.

61. Li C, Kong Y, Wang H, Wang S, Yu H, Liu X, Yang L, Jiang X, Li L, Li L (2009) Homing of bone marrow mesenchymal stem cells mediated by sphingosine 1-phosphate contributes to liver fibrosis. Journal of hepatology. 50(6):1174-1183.

62. Henderson, W.R. Jr, Chi, E.Y., Ye, X., Nguyen, C., Tien, Y.T., Zhou, B., et al. (2010) Inhibition of Wnt/beta-catenin/CREB binding protein (CBP) signaling reverses pulmonary fibrosis. Proc. Natl. Acad. Sci. U S A. 107: 14309-14314.

63. Akhmetshina, A., Palumbo, K., Dees, C., Bergmann, C., Venalis, P., Zerr, P. et al., (2012) Activation of canonical Wnt signalling is required for TGF- $\beta$-mediated fibrosis. Nat. Commun. 3: 735-746.

64. Parekkadan, B., Van Poll, D., Suganuma, K., Carter, E. A., Berthiaume, F., Tilles, A. W., Yarmush, M. L. (2007) Mesenchymal stem cellderived molecules reverse fulminant hepatic failure. PloS one. 2(9): e941, 6 pages.

65. Huang, B., Cheng, X., Wang, H., Huang, W., Wang, D., Zhang, K., Zhang, H., Xue, Z., Da, Y., Zhang, N., Hu, Y. (2016) Mesenchymal stem cells and their secreted molecules predominantly ameliorate fulminant hepatic failure and chronic liver fibrosis in mice respectively. Journal of translational medicine. 14(1): 45, 12 pages

66. Van Poll, D., Parekkadan, B., Cho, CH., Berthiaume, F., Nahmias, Y., Tilles, A.W., Yarmush, M.L. (2008) Mesenchymal stem cellderived molecules directly modulate hepatocellular death and regeneration in vitro and in vivo. Hepatology 47: 1634-1643.

67. Pawitan, J.A. (2014) Prospect of stem cell conditioned medium in regenerative medicine. BioMed research international. 2014; 14 pages.

68. Samad, S., Akram, K.M., Forsyth, N.R., Spiteri, M. (2014) Mesenchymal Stem Cell Conditioned Media (MSC-CM) suppress Wnt-3a and TGF- $\beta 1$ induced myofibroblastic differentiation. J Stem cell Res, Rew and Rep. 1: 1015-1021.

69. Hass, R., Kasper, C., Bohm, S., Jacobs, R. (2011) Different populations and sources of human mesenchymal stem cells (MSC), A comparison of adult and neonatal tissue-derived MSC. Cell Commun Signal. 9: 12-25. 
70. Radaeva, S., Sun, R., Jaruga, B. et al. (2006) Natural killer cells ameliorate liver fibrosis by killing activated stellate cells in NKG2Ddependent and tumor necrosis factor-related apoptosis- inducing ligand-dependent manners. Gastro- enterology.130: 435-452.

71. Wuchter, P., Bieback, K., Schrezenmeier, H. et al. (2014) Standardization of GoodManufacturing Practice-compliant production of bone marrowderived human mesenchymal stromal cells for immunotherapeutic applications. Cytotherapy.
17(2): 128-39. doi: 10.1016/j.jcyt.2014.04.002.

72. Khosravi, A., Cutler, C. M., Kelly, M. H. et al. (2007) Determination of the elimination halflife of fibroblast growth factor-23. Journal of Clinical Endocrinology and Metabolism. 92(6): 2374-2377.

73. Yde, P., Mengel, B., Jensen, M. H., Krishna, S., Trusina, A., (2011) Modeling the NF-kB mediated inlammatory response predicts cytokine waves in tissue. BMC Systems Biology. 5(1): 115-123 
الملخص العربى

مقارنة التأثير ات العلاجية للخلايا الجذعية الوسيطة مقابل الوسائط المكيفة لها في تحسين تليف الكبا المستحث باستخدام رابع كلوريد الكريون في الفئران : دراسة نسيجية وكيميائية الوية حيوية

سارة عبد العال 1 ، شيماء عبد الرحمن ، ، نيرمين رأفت

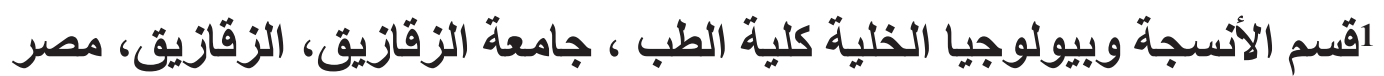
2قسم البيوكيميا الطبيه، كليه الطب، جامعة بنها، بنها، مصر جله

الخلفية: التهاب الكبد الفيروسي ، وتعاطي المخدرات والأمر اض الأيضيه تسبب إصابة الكبد. يمكن أن توفر الوسائط المكيفة للخلايا الجذعية وحدها إصلاح الأعضاء الفير مقارنةً بالخلايا الجذعية.

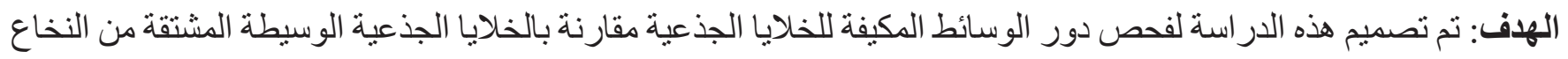

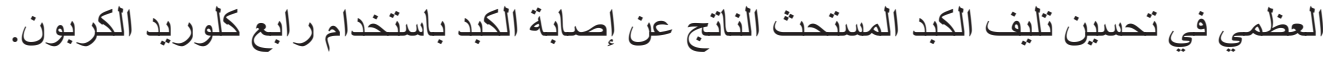

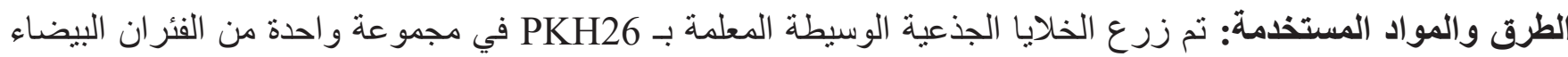

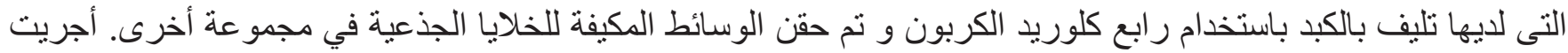

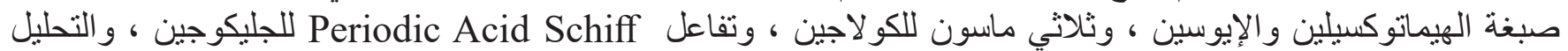

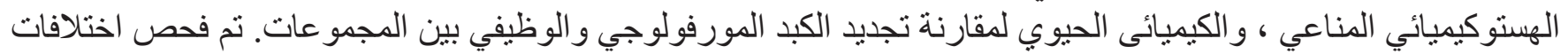
التعبير عن CYP7A1 C CYP27A1 ، الجلوتاثيون اختزال ، الجلوتاثيون بيروكسيديز ، الألبومين و الإنترلوكينات عن طريق تفاعل سلسلة البلمرة في الوقت الحقيقي (RT-PCR) و الفحص المناعي المرتبط بالإنزيم (ELISA).

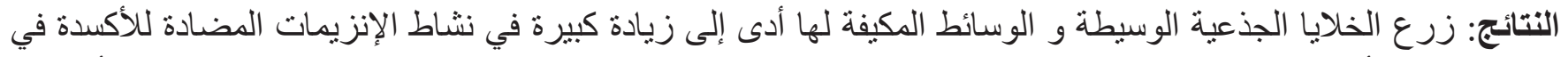

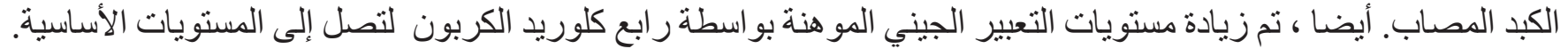

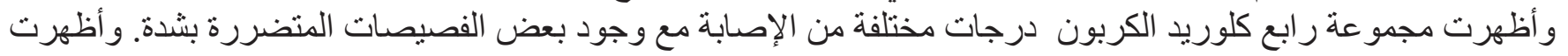

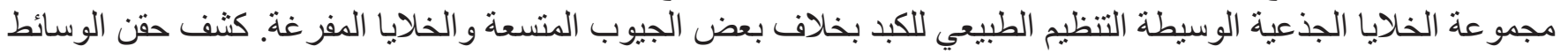
المكيفة للخلايا الجذعية الصورة الطبيعية للكبد نسيجيا ومناعيا.

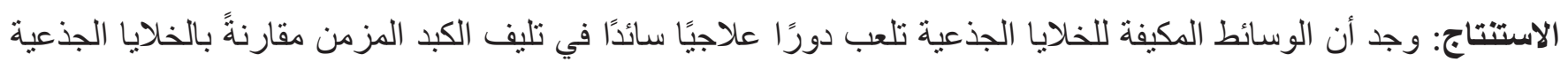
الوسيطة المشتقة من النخاع العظمي. 